JURNAL PENDIDIKAN MATEMATIKA DAN IPA

Vol 12, No. 1 (2021) h. 1-10

http://jurnal.untan.ac.id/index.php/PMP

\title{
ERROR ANALYSIS OF ISLAMIC PRIMARY SCHOOL (MTs) STUDENTS IN RESOLVING QUESTIONS ON THE MATERIALS OF CARTESIAN COORDINATE WITH MALAY CULTURE NUANCE IN RIAU
}

\author{
Bahrin, Maimunah, Yenita Roza \\ Graduate Program In Mathematics Education at State University of Riau, Simpang Baru, \\ Kecamatan Tampan, Pekanbaru 28293, Indonesia \\ E-mail: bahrin7040@grad.unri.ac.id
}

DOI: $10.26418 /$ jpmipa.v12i1.43145

\begin{abstract}
Students experience problems while working in Math, with full of difficulties. They made mistakes in the process of solving questions. The error process that occurred in students leads to the low achievement of the learning outcomes. This research aimed to investigate the mistakes made by MTs students in working on the questions of the Cartesian coordinate integrated with Malay cultural nuances in Riau Province. The study was conducted at MTs in the odd semester of the 2019/2020 academic year. A descriptive approach was used as a research method with a purposive sampling technique. This technique used a test and interview to collect research data. The results of the study described that the errors faced by MTS NurulBilad students included: (1) 55\% of misconceptions because students did not understand the concept in the material of Cartesian coordinate (2) procedural errors that $76 \%$ of students did not match the stages or steps in the process of drawing on the Cartesian coordinate. Based on the findings, it was hoped that the teacher emphasized more understanding about the concept of Cartesian coordinate.
\end{abstract}

Keywords: Error Analysis, concept, procedural, Cartesian coordinate.

\section{INTRODUCTION}

Mathematics is a subject that has been learned from elementary school up to advanced education level. It is due to that Maths really helps human in performing daily activities. This statement is relevant to Abdullah (2017); mathematics is an action that has an essential role in everyday life. The benefits for students are to sharpen the mindset of the students and to train precision and accuracy. However, in Math, students are less interested in 
learning this lesson. Students think that Mathematics is hardly difficult to understand and contains lots of formulas to memorise so that students are saturated in learning this subject. The difficulties faced by the students in resolving the problems, if untreated, will lead them to make mistakes. This statement is relevant to Anugrah \& Pujiastuti (2020) that the difficulty of resolving the problems can generate errors. Most students experience errors in completing Math questions due to students only guessed the answers without assessing the process of resolving them.

An error analysis is one method that can identify a process of an origin error, especially in resolving Math problems. One of the teacher's efforts in investigating the errors made by the students is by performing research. Therefore, Herutomo \& Saputro (2014) demonstrated that the student's mistakes would be determined by searching further in the process of thinking and reasoning from students in completing questions. The student's error in accomplishing the math questions should be analysed for correction and improvement to increase learning outcomes maximally and adequately. This opinion follows another statement from Jusniani (2018); it is necessary to analyse questions for avoiding any errors generated by the students to understand and proceed to further investigation to achieve maximal learning outcomes.

Error in resolving some questions is acceptable. However, if it happens consistently and too much, then it is necessary to be fixed. Wahbi \& Bey (2015) also mentioned that students make mistakes in completing maths questions without further correction; this might trigger students to have difficulty learning maths. According to Munandar (2002), an error is defined as a systematic deviation in certain parts. Hence, the error tailored here is, students deviate at the processing of questions completion from the determined answered. Therefore, teachers should be capable of teaching students to complete questions of both routines and non-routines assignments to avoid repeating similar mistakes.

The errors that emerged in eightgrade students of Islamic Primary School (MTs VIII-A) were essential to analyse to discover the reasons. By performing this error analysis, it helps us to answer and obtain the expected results. Mistakes generated from students in resolving questions may promote teachers to provide direction/assistance to students. This is relevant to this statement by Ananda, et al. (2018); a happened mistake is required to analyse as to know the reason for it. Student misconduct in solving mathematical problems commonly occurred in the process of problem completion or against the procedure. The form of the error made by students is a deviation that does not correspond with the answers.

A wide variety of types of error showed from students in working the maths problems. According to Badaruddin, et al. (2016), it comprised the faults of concept, principle, and procedural. According to Salido, et al. (2014), it may limit the errors to become the faults of concept, principle and procedural. A mistake that can be taken in this research can be developed based on the description of the above opinion. As for the type of errors made by MTs students is an error of concept and procedural. 
According to Fathani \& Hakim (2009), a concept is an abstract notion that may be classified as a group of objects, either as an example or non-example. Meanwhile, according to Arends \& Richard (2008), a concept is a thing that may organise and experience a cognitive object in several categories. A student has mastered the concept of cartesian coordinate. According to Sari (2017), the indicator of misconception classifies an object based on its characteristics. The indicators of misconception in this study were:

a. Error in determining the solutions to solving the problems.

b. Not understand the rules in completing questions.

c. Imprecisely writing answers from the asked questions.

Procedural is the steps counted in the process of question completion, which is in accordance with the plots so that students will not do any deviations that have been defined. The indicators of procedural errors cover:

a. The discrepancy in the stage of solving problems done by students.

b. Students do not perform the steps in resolving problems until completed.

Permendikbud No. 35 in 2018 stated that the 2013 curriculum was developed based on three things, i.e., the characteristics of the Indonesian culture variety, the focus in creating a better life at present and in the future. Learning on curriculum 2013 leads students to encounter the competence of a good life in the present nor future. Then, they can develop their skills in Malay culture. A culture is a component applied in the 2013 curriculum from the basic level to the upper secondary level. According to Wahyuni \& Pertiwi (2017), culture is a human habit/belief obtained from society passed on through generations. The application of cultural values in the 2013 curriculum can be implemented through learning to students so that they can recognise the cultures surrounding them.

To introduce students to Riau Malay culture, in this study, researchers associated questions on the material of cartesian coordinate with the nuances of Malay culture in Riau. According to Khatimah \& Asdarina (2020), mathematical learning must be adapted to the culture. Through the Governor Regulation No. 72 in 2015, the Government of Riau Province stated that the subject of local knowledge must be implemented in the Riau Province, namely on the subjects of Riau Malay Culture (BMR). This subject describes the Riau Malay culture, including the history, aesthetics, and habits of a tradition and other subjects. The subject aims to introduce the natural environment of the region. In this study, researchers integrated this subject to mathematics. In mathematics, the cartesian coordinate material enables the integration of a map of the Riau Region.

According to Putri (2017), cultures are aesthetics and ideas in a group of people in a particular environment. The interconnection of cultures with mathematics is called Ethnomathematics. According to Hardiarti (2017), the word "ethno" refers to a culture's context, including jargon, myths, language, and symbols. "Mathema" is a performing activity, including conclusion and mathematical modelling. The word "tics" is derived

Bahrin, Maimunah \& Yenita Roza

Error Analysis of Islamic Primary School (MTs) Students in Resolving Questions on The Materials of Cartesian Coordinate With Malay Culture Nuance In Riau 
from the word of techne, which means a technique. According to Masamah (2018), Ethnomathematics is the learning of mathematics that associates with a culture with the aim of mathematics learning that may become more meaningful.

According to Hasanah, et al. (2019), Ethnomathematics is a group culture that is exhibited in the mathematical form, for instance, rate and count. Thus, it can be concluded that the Ethnomathematics is the learning activity to associate culture with mathematics. In this study, researchers integrated questions on the material of the cartesian coordinate in Malay culture's nuances in Riau. In mathematics, there is a cartesian coordinate material that allowed integrating a map of the region of Riau Province. This material was presented through the KD 3.2 and KD 4.2 for class VIII.

\section{METHODS}

This research was conducted at MTs on March 11, 2020. The subjects in this research were students from class VIII $A$ in the even semester of the academic year 2019/2020. This study used a qualitative method with a descriptive approach. Researchers described a data from the studied information, which means only information that would be examined at the time of study would have been executed, for example, solving the problems and then describing them in the form of words. Data collection in this study was conducted using test and interview methods so that the obtained data would clearly be described. This study's main concern was the results of the mathematics test done by students on the principal material of the cartesian coordinate. In the determination of subject with purposive sampling, the subject collection was done with explicit consideration by investigating students' common errors.

\section{RESULTS AND DISCUSSION}

Based on the test results of question elaboration, it was found that four questions were associated with the material of Cartesian coordinate in the nuances of Riau Malay Culture. This result was integrated into the map of Riau province, which was given to 25 students, shown in Table 1.

Table 1. The Percentage of Error Students

\begin{tabular}{ccccccc}
\hline $\begin{array}{c}\text { The } \\
\text { Analysis of } \\
\begin{array}{c}\text { Student } \\
\text { Answers }\end{array}\end{array}$ & $\mathbf{1}$ & $\mathbf{2}$ & $\mathbf{3}$ & $\mathbf{4}$ & The total students with errors & Error \% \\
\hline $\begin{array}{c}\text { Conceptual } \\
\text { Error }\end{array}$ & 0 & 12 & 15 & 14 & 41 & 55.00 \\
$\begin{array}{c}\text { Procedural } \\
\text { Error }\end{array}$ & 0 & 0 & 20 & 18 & 38 & 76.00 \\
\hline
\end{tabular}

Bahrin, Maimunah \& Yenita Roza

Error Analysis of Islamic Primary School (MTs) Students in Resolving Questions on The Materials of Cartesian Coordinate With Malay Culture Nuance In Riau 
Table.1 demonstrated that the type of errors from questions on the cartesian material coordinate with the nuances of Malay culture in Riau. The most common error that resulted in students was the procedural error with a percentage of $76 \%$. This happened due to the students who did not follow the procedural indicator while resolving problems. The procedural indicator is a discrepancy in the conduct of completing questions made by students where they did not follow the steps in solving problems until completed. Furthermore, students' rare error indicator was the error in conceptual with a percentage of $55 \%$. This error emerged due to students were less comprehended the concept of cartesian coordinate.

The indicator of conceptual error was that the students did not understand the rules in completing questions and were precisely incorrect in writing the answers for the asked questions.

If it was viewed from each question,

\section{Conceptual error}

According to Kristanti (2020), student errors are the students' fault in understanding the concept of a material or an error in completing the question. The conceptual errors performed by the MTs students in the material of cartesian coordinate with the nuances of Riau Malay the student mostly answered correctly for the question number 1. Meanwhile, for question number 2, thirteen pupils answered correctly, and twelve pupils were classified into wrong answers. On the other hand, question number 3, five students answered correctly, and twenty students were grouped into the wrong answers in resolving the question. Last, question number 4, seven pupils answered correctly, and eighteen pupils were in the group of incorrect answers.

In practice, the questions were provided after finishing the material of the cartesian coordinate. The aim was to determine the levels of student errors. From the results of student tests in the cartesian coordinate material, it was found the students' errors. These mistakes done by the students in completing the problems in the material of cartesian coordinate were divided into two categories, conceptual and procedural errors. It was presented in the picture below:

Culture were the students did not master the rules in resolving the problems in the material of cartesian coordinate. In this context, the questions were depicted in integrating the map of Riau province, including the hills and the streams from the Rokan river in Riau province. 


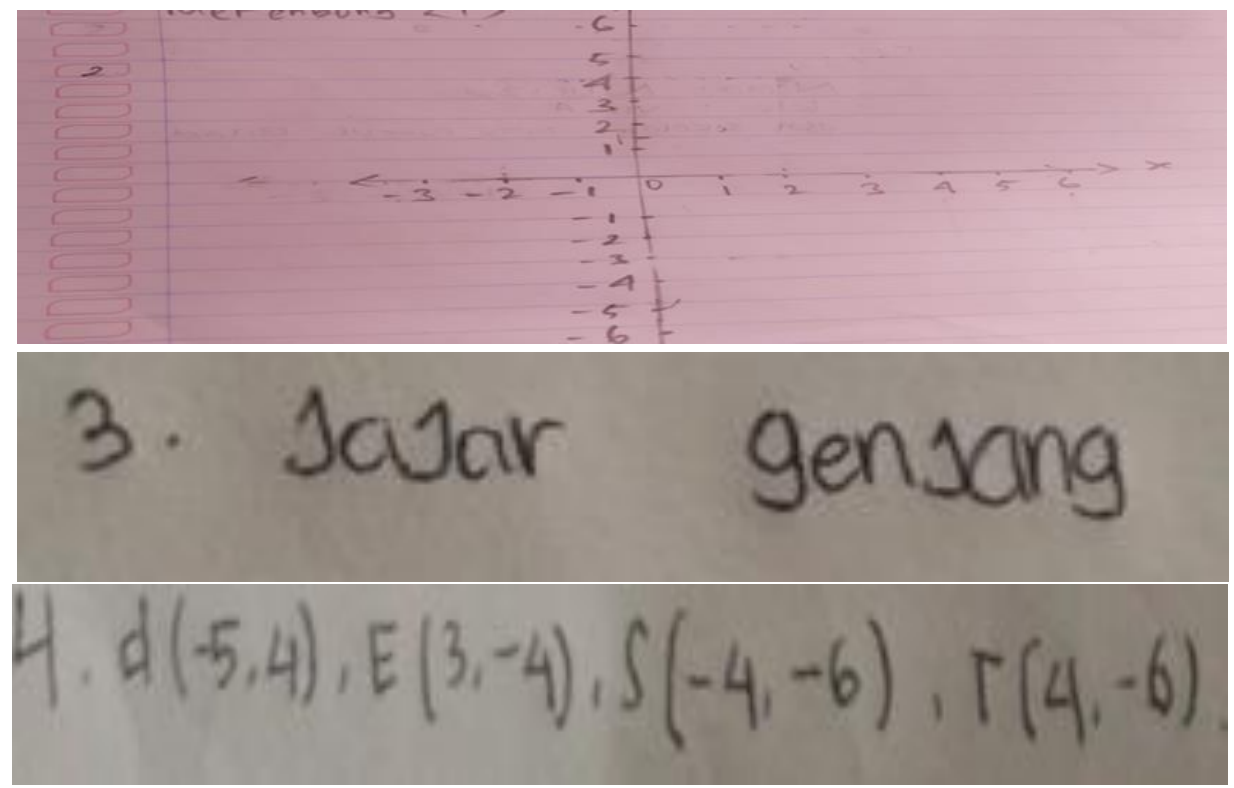

Figure 1. The Results of Student Work-ABC

Figure 1 exhibited that the results of student work-ABC, which seemed not to understand the concept of cartesian coordinate in the form of Riau Malay Culture nuances, were integrated into the map of Riau province. The indicators of the concept errors were the degree levels where students did not comprehend the conditions in resolving the questions and were precisely incorrect in answering the related questions. The process of performing resolution on the number 2,3 and 4 is not under the indicators on the concept's fault because the student did not understand the point in the field by using two numbers, namely the $\mathrm{x}$ and $\mathrm{y}$ coordinate. This was in accordance with research Wandy et al. (2019) that the ability to understand concept and abstraction in students was low.
Furthermore, for questions number 3 and 4, the students were asked to draw cartesian coordinates where the $\mathrm{x}$-axis and $y$-axis were known. In this case, the students could not differentiate between the $x-y$ axis so that students guessed the axes unexpectedly and placed them in the incorrect points. Moreover, students could not complete all questions provided. This incompetence was shown clearly from the results of the students' answers in resolving the problems.

In this study, researchers performed interviews with students. The results of the interviews revealed that students still doubted in drawing the coordinate of the $x-y$ axis. Other students claimed that by doing this way, they could finish the tasks quickly where the answers provided by them were not based on the concepts required. They just guessed 
and answered thoughtlessly because they were reluctant to recheck the answers with the key answers provided prior. They were also embarrassed to ask

\section{Procedural Error}

According to Khatimah \& Asdarina (2020), an error is a fallacy of what is right. The procedural error in this context was that the students did irregularities in the completion process of cartesian coordinate problems in Riau further to the related teacher. The reason behind this reluctancy was that the students thought it might bother the teachers during the learning activity.

Malay culture nuances, which was integrated into a map of Riau Province. The list of procedural errors recorded from student misconduct was displayed in the figure below.
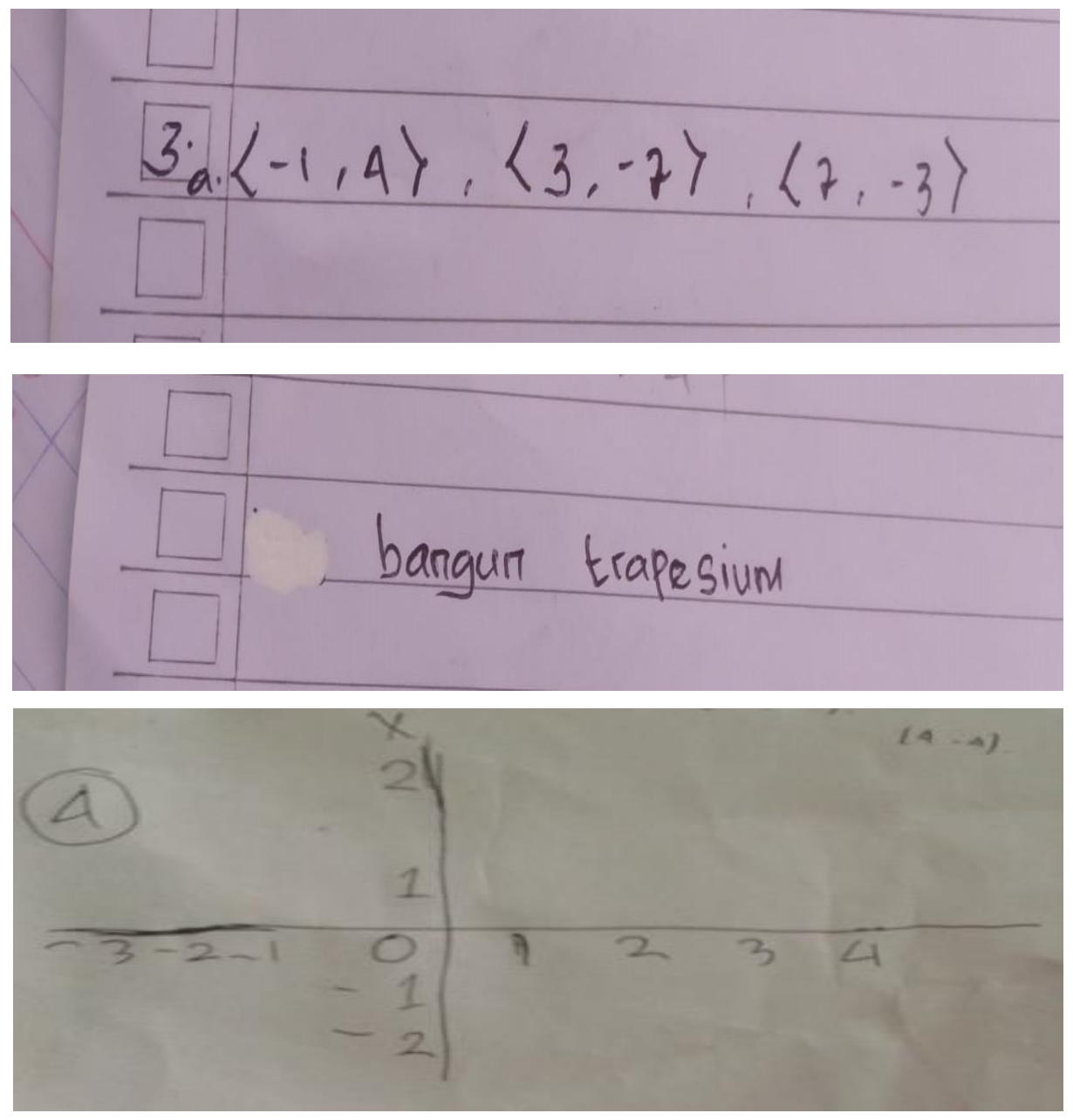

Figure 2. The Work Results of Students-XYZ 
The error that followed in this study was determined after examining the student works' results while completing the questions on the material cartesian coordinate. This error type was still temporary, so the researchers continued to the interview stage to ascertain the error type. As for the interview stages, it was collected five pupils as the interview subjects. The subject collection for the interview was defined from the type/variation of the student errors. From the test and interview results, the five students matched with the demanded criteria to ascertain the type of student misconduct. Furthermore, the results of both tests and interviews were carefully analysed so that researches understood the concrete results of the errors performed by students MTs Nurul Bilad VIIIA.

The student interview results were obtained after completing the assessment stages of the test results on the questions of the cartesian coordinate. Based on the five students' interviews, it was exhibited that the students were still challenging to understand the concepts and steps in solving the questions of cartesian coordinates with the nuances of Malay culture in Riau because they did not regularly answer the type of questions. Then, it was continued with the interviews of the teachers afterward. From the results of the interviews with teachers, it was found that the students were not really fond of maths. However, only some of the students who showed less interest in learning the material of cartesian coordinates. This was due to their assumptions that the material is not massively impactful on them. The causes of the error that occurred in the students were, the students assumed that the material of cartesian coordinates has no benefit for them, the learning interest of students in the process of mathematics learning was relatively low, and during the teacher's explanation, the student was difficult to understand. Learning maths that is discontinued may considerably interfere with the learning process.

\section{CONCLUSION}

Based on the error analysis results on the students of VIII-A MTs Nurul Bilad, it was reported that students made both conceptual and procedural errors. The most error made by students was the procedural error. Students were still wrong in answering the questions of the cartesian coordinate. The indicator of this procedural error was the discrepancy in the conduct of completion stages of students' questions, and students did not follow the steps in resolving them until completed. Meanwhile, the conceptual error was the students' difficulty while understanding the concept of the cartesian coordinate. The indicator of this conceptual error was the nonunderstanding of the rules in resolving questions and imprecision in answering them in the nuances of Riau Malay Culture.

\section{REFERENCE}

Abdullah, A. S. (2017). Ethnomathematics in Perspective of Sundanese Culture. Journal on Mathematics Education, 8(1), 116.

Ananda, R. P., Sanapiah, S., \& Yulianti, S. (2018). Analisis Kesalahan Siswa Kelas VII SMPN 7 Mataram Dalam Menyelesaikan Soal Garis

Bahrin, Maimunah \& Yenita Roza

Error Analysis of Islamic Primary School (MTs) Students in Resolving Questions on The Materials of Cartesian Coordinate With Malay Culture Nuance In Riau 
Dan Sudut. Media Pendidikan Matematika, 6(2), 79-87.

Anugrah, A., \& Pujiastuti, H. (2020). Analisis Kesalahan Siswa dalam Menyelesaikan Soal HOTS Bangun Ruang Sisi Lengkung. Jurnal Pendidikan Matematika, 11(2), 213-225.

Arends, \& Richard. (2008). Learning To Teach Belajar Untuk Mengajar. Pustaka Belajar.

Badaruddin, Kadir, \& Anggo, M. (2016). Analisis Kesalahan Dalam Menyelesaikan Soal-Soal Operasi Hitung Pecahan Pada Siswa Kelas VII Smp Negeri 10 Kendari. Jurnal Penelitian Pendidikan Matematika, 4(2), 43-56.

Fathani, \& Hakim, A. (2009). Matematika Hakikat dan Logika. Ar-ruzz Media.

Hardiarti,

S. (2017).

Etnomatematematika: Aplikasi Bangun Datar Segiempat pada Candi Muaro Jambi. Aksioma, 8(2), 99-110.

Hasanah, S. I., Hafsi, A. R., \& Zayyadi, M. (2019). Pengembangan Lembar Kerja Siswa Berbasis Etnomatematika Dalam Membangun Pemahaman Konsep Siswa. Jurnal Pendidikan Matematika Dan IPA, 10(2), 183191.

Herutomo, R. A., \& Saputro, T. E. M. (2014). Analisis Kesalahan Dan Miskonsepsi Siswa Kelas VIII
Pada Materi Aljabar. Edusentris, 1(2), 134-145.

Jusniani, N. (2018). Analisis Kesalahan Jawaban Siswa Pada Kemampuan Pemahaman Matematis Melalui Pembelajaran Kontekstual. Prisma, 7(1), 82-90.

Khatimah, H., \& Asdarina, O. (2020). Diagnosis Kesalahan Siswa dalam Memahami Materi Faktorisasi Bentuk Aljabar pada Siswa Kelas VIII. Mathema: Jurnal Pendidikan Matematika, 2(1), 40-56.

Kristanti, D. (2020). Scaffolding Sebagai Upaya Mengatasi Kesalahan Matematika Siswa Kelas VIII. Jurnal Pendidikan Matematika Dan Matematika, 2(1), 54-65.

Masamah, U. (2018). Pengembangan Pembelajaran Matematika Dengan Pendekatan Etnomatematika Berbasis Budaya Lokal Kudus. Jurnal Pendidikan Matematika, 1(2), 123-144.

Munandar, U. (2002). Pengembangan Kreativitas Anak Berbakat. Rineka Cipta.

Putri, L. I. (2017). Eksplorasi Etnomatematika Kesenian Rebana Sebagai Sumber Belajar Matematika Pada Jenjang Mi. Jurnal Ilmiah Pendidikan Dasar, IV(1), 21-31.

Salido, A., Misu, L., \& Salam, M. (2014). Analisis Kesalahan Siswa Dalam Menyelesaikan Soal-Soal Matematika Materi Pokok Limit 
Fungsi Pada Siswa Kelas XI IPA 2 SMA Negeri 5 Kendari. Jurnal Penelitian Pendidikan Matematika, 1(2), 1-13.

Sari, P. (2017). Pemahaman Konsep Matematika Siswa pada Materi Besar Sudut Melalui Pendekatan PMRI. Jurnal Gantang, 2(1), 4150.

Wahbi, A., \& Bey, A. (2015). Analisis Kesalahan Siswa Dalam Menyelesaikan Soal Faktorisasi Suku Aljabar Ditinjau Dari Objek Matematika Pada Siswa Kelas VIII SMP Negeri 15 Kendari. Jurnal Penelitian Pendidikan Matematika, 3(1), 17-30.

Wahyuni, A., \& Pertiwi, S. (2017). Etnomatematika dalam ragam hias melayu. Math Didactic: Jurnal Pendidikan Matematika, 3(2), 113-118.

Wandy, S., Roza, Y., \& Maimunah. (2019). Identifikasi Kesalahan Konseptual Dan Prosedural Siswa Dalam Menyelesaikan Soal Pada Materi Dimensi Tiga. Jurnal Pendidikan Matematika, 3(2), 494-503.

Wati, R., \& Ningtyas, Y. D. W. K. (2020). Analisis Kesalahan Koneksi Matematis Siswa dalam Menyelesaikan Masalah Kontekstual ditinjau dari Kemampuan Matematis Siswa. Jurnal Gammath, 5(1), 44-52. 